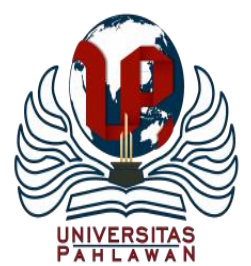

Jurnal Basicedu Volume 5 Nomor 1 Tahun 2021 Halaman 10-18

JURNAL BASICEDU

Research \& Learning in Elementary Education

https://jbasic.org/index.php/basicedu

\title{
Analisis Kesulitan Belajar Membaca Anak Berkebutuhan Khusus di Sekolah Dasar
}

\author{
Asep Supena ${ }^{1}$ Robiatul Munajah ${ }^{2}$ \\ Universitas Negeri Jakarta, Indonesia ${ }^{1}$ \\ Universitas Trilogi, Indonesia ${ }^{2}$

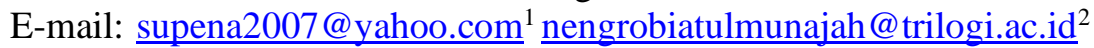

\begin{abstract}
Abstrak
Kontroversi mengenai pendidikan membaca meningkat ketika kita mempertimbangkan anak-anak dengan ketidakmampuan belajar. Keberhasilan akademis memainkan peran integral dalam kehidupan anak-anak, yang memengaruhi perkembangan dasar mereka. Namun, para guru sekolah hanya mengetahui sedikit tentang dampak emosional dari ketidakmampuan belajar pada anak-anak yang kesulitan di sekolah, terutama mereka yang kesulitan membaca, karena efeknya yang menyeluruh pada semua mata pelajaran lainnya. Oleh karena itu, sangatlah penting bagi guru untuk menciptakan lingkungan yang aman dimana siswa merasa nyaman untuk belajar dengan kesulitan membaca. Dari hasil penelitian studi deskriptif didapatkan tiga temuan utama yang dapat dideskripsikan dalam penelitian ini berdasarkan hasil wawancara, observasi dan dokumentasi serta diperkuat dengan kajian teori dari berbagai referensi. Tiga kategori utama tersebut yaitu pertama karakteristik anak kesulitan belajar berkaitan dengan kemampuan membaca, kedua kondisi temuan di lapangan khususnya di SDN Inklusif Sukasari 01 Pandeglang, ketiga solusi atau penanganan yang dapat dilakukan oleh guru dan orang tua dengan memberikan treatment untuk mengatasi kesulitan dan hambatan belajar yang dialami siswa berkebutuhan khusus dengan kesulitan belajar pada kemampuan membaca.
\end{abstract}

Kata kunci: studi deskriptif, kemampuan membaca, kesulitan belajar

Abstract

Controversy regarding reading education increases when we consider children with learning disabilities. Academic success plays an integral role in children's lives, influencing their basic development. However, school teachers know little about the emotional impact of learning disabilities on children who struggle at school, especially those with reading difficulties, because of their overall effect on all other subjects. Therefore, teachers need to create a safe environment where students feel comfortable learning with reading difficulties. From the results of the descriptive study, three main findings can be described in this study based on the results of interviews, observation, and documentation and strengthened by theoretical studies from various references. The three main categories are the first characteristics of children with learning difficulties related to reading skills, the second is the condition of findings in the field, especially at SDN Inclusive Sukasari 01 Pandeglang, the third solution or treatment that teachers and parents can do by providing treatment to overcome learning difficulties and obstacles experienced by students with special needs with learning difficulties in reading skills.

Keywords: descriptive study, reading ability, learning disabilities

Copyright (c) 2021 Robiatul Munajah, Asep Supena

$\square$ Corresponding author
Address : Kalibata Jakarta Selatan
Email $\quad:$ nengrobiatulmunajah@ $@$ trilogi.ac.id
Phone $\quad: 089682773130$
DOI: https://doi.org/10.31004/basicedu.v5i1.558

ISSN 2580-3735 (Media Cetak)

ISSN 2580-1147 (Media Online)

DOI: https://doi.org/10.31004/basicedu.v5i1.558 


\section{PENDAHULUAN}

Pendidikan merupakan hak semua warga negara tanpa kecuali. Hak pendidikan tidak membedakan derajat, kondisi ekonomi ataupun kelainannya. Semua berhak memperoleh pendidikan yang layak. Semua berhak memperoleh pendidikan yang ada disekitarnya. Pendidikan merupakan kebutuhan dasar setiap manusia untuk menjamin keberlangsungan hidupnya agar lebih bermartabat. Karena itu negara memiliki kewajiban untuk memberikan pelayanan pendidikan yang bermutu kepada setiap warganya tanpa terkecuali termasuk mereka yang memiliki perbedaan dalam kemampuan (difabel) seperti yang tertuang pada UUD 1945 pasal 31 (1) (Nasional, 2007).

Guru dan siswa memiliki peran yang tidak terpisahkan dalam proses pembelajaran. Belajar dapat dijalankan dengan baik jika mereka memiliki kesadaran belajar dan mengajar satu sama lain. Namun kadang-kadang ada masalah yang datang dari siswa dan guru tidak menyadarinya. Kesulitan belajar merupakan masalah yang ditemukan siswa dan membutuhkan perhatian khusus dari guru.

Kesulitan belajar bervariasi dan mencakup kelompok gangguan heterogen. Seorang anak dengan gangguan kesulitan belajar mungkin tidak memiliki jenis masalah pembelajaran seperti anak lain dengan kesulitan belajar lainnya. Fried mengungkapkan bahwa seseorang dengan kesulitan belajar mungkin memiliki masalah dengan memahami matematika. Anak lain mungkin mengalami kesulitan memahami apa yang orang katakan. Oleh karena itu, tidak ada profil tunggal individu dengan kesulitan belajar dapat akurat karena perbedaan antar-individu dalam gangguan (Suryandari, 2020).

Anak dengan kesulitan belajar adalah salah satu gangguan yang ditangani di sekolah inklusi. Anak dengan gangguan ini menunjukkan pemrosesan informasi yang lemah. Pemrosesan informasi dapat menjadi tantangan baik dari segi kemampuan sosial seperti memahami bahasa sarkasme, mengartikan bahasa tubuh atau mengingat kembali informasi. Anak dengan gangguan ini memiliki tingkat kecerdasan di atas rata-rata namun memiliki kesulitan dalam membaca, menulis dan menghitung. Hal yang terganggu pada anak dengan learning disability adalah persepsi yang salah mengenai bentuk huruf, bunyi huruf ataupun angka (Ontario Rusmono, 2019).

Guru mendapati perilaku dari siswa berkebutuhan khusus membawa beban dalam proses pengajarannya. Pengetahuan guru mengenai siswa berkebutuhan khusus belum merata sehingga penanganan yang diberikan oleh guru juga tidak sama antara satu guru dengan yang lain.

Guru dari lulusan pendidikan luar biasa juga dinilai masih memiliki kemampuan yang kurang dalam menangani siswa berkebutuhan khusus. Guru masih menyamaratakan metode pengajaran siswa berkebutuhan khusus dengan siswa reguler. Ketidakmampuan guru dalam menangani siswa berkebutuhan khusus meliputi profesionalisme guru yaitu masih ada guru yang latar belakang pendidikannya tidak berasal dari pendidikan luar biasa, masih rendahnya kompetensi guru dalam merencanakan program pendidikan inklusi. 
Berdasarkan hasil penelitian sebelumnya dapat dimaknai bahwa perlu bagi pendidik atau guru mengetahui dan memahami bagaimana menangani anak dengan kesulitan belajar pada sekolah dasar inklusi. Dalam penelitian ini penulis bermaksud mendeskripsikan tentang kemampuan membaca pada anak dengan kesulitan belajar di sekolah inklusi SDN inklusif sukasari 01 Pandeglang berdasarkan pengamatan dan temuan di lapangan.

\section{METODE}

Penelitian ini menggunakan pendekatan kualitatif dengan metode deskriptif. Penelitian kualitatif dengan metode deskriptif adalah metode yang menjelaskan atau mendeskripsikan suatu fakta, data, dan objek penelitian secara sistematis dan sesuai dengan situasi alamiah. Terkait hal yang diteliti, hasil penelitian lebih menekankan pada makna dari pada hasil, dan hasil penelitian tidak mengikat serta dapat berubah sesuai dengan kondisi yang dihadapi di lapangan penelitian dan diinterpretasikan dan dituliskan dalam bentuk katakata atau deskriptif berdasarkan fakta di lapangan (Anggito \& Setiawan, 2018).

Peneliti berperan sebagai human instrument (peneliti melakukan penelitiannya sendiri). Pengambilan sampel dan sumber data dilakukan secara purposive sampling (pengambilan sampel berdasarkan atas sebuah pertimbangan yang berfokus pada tujuan tertentu dan peneliti sudah menentukan sebuah kriteria pada pengambilan sampelnya), pengambilan sampel berdasarkan kebutuhan dan sesuai dengan topik penelitian. Teknik pengumpulan data menggunakan wawancara, observasi, dan dokumentasi. Analisis data bersifat kualitatif, dengan menggunakan model Milles \& Huberman. Pemeriksaan keabsahan data, menggunakan triangulasi teknik, meningkatkan ketekunan, dan menggunakan bahan referensi.

Sumber data dalam penelitian adalah subjek mengenai perolehan data yang telah didapat. Datadata yang kemudian dijadikan acuan dalam penelitian ini diambil dari berbagai sumber di antaranya:

1) Sumber Data Primer

Data Primer merupakan data yang diperoleh langsung dari subjek yang diteliti, dalam mengumpulkan data primer, peneliti harus kontak atau komunikasi langsung dengan subjek ataupun informan dalam penelitian, maka dari itu, pada penelitian ini sumber data yang didapatkan berasal dari subjek atau informan yang akan diwawancarai dan diobservasi oleh peneliti yang dilakukan langsung di tempat penelitian.

2) Sumber Data Sekunder

Data sekunder merupakan data pelengkap untuk mendukung data primer.

Teknik analisis data yang digunakan dalam penelitian ini adalah menggunakan model Milles dan Huberman, yaitu analisis dalam penelitian dilakukan secara interaktif.

1) Reduksi Data (Reduction)

Peneliti menulis ulang atau merangkum hasil data yang didapatkan pada dari hasil observasi, wawancara, dan dokumentasi. (Milles \& Huberman, 2013)

2) Penyajian Data (Data Display) 
Setelah mereduksi data, langkah selanjutnya adalah melakukan penyajian data (display data). Data yang diperoleh dalam penelitian ini disajikan dalam bentuk uraian singkat yang bersifat naratif (dengan teks) (Milles \& Huberman, 2013).

3) Penarikan Kesimpulan (Verification) Langkah terakhir pada analisis data adalah membuat kesimpulan. Peneliti akan menarik atau membuat kesimpulan dengan memberikan penjelasan dari kegiatan pengambilan data melalui observasi, wawancara, dan didukung oleh dokumentasi (Milles \& Huberman, 2013).

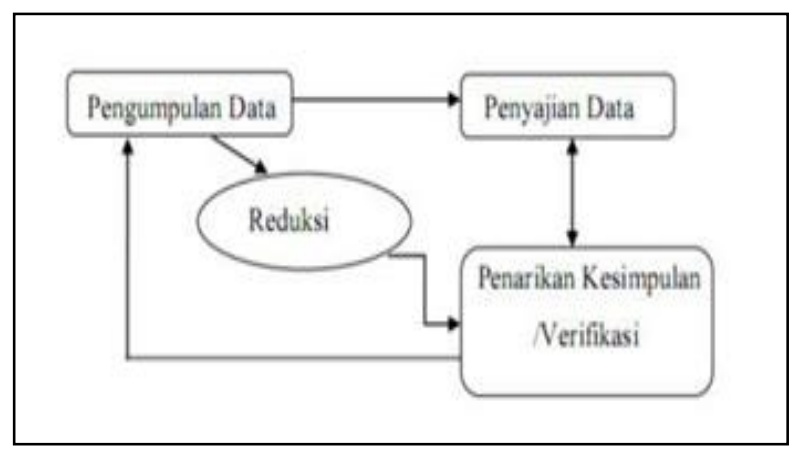

Gambar 1. Analisis Data Interaktif model Hubberman dan Miles

Teknik pemeriksaan keabsahan data yang digunakan oleh peneliti dalam penelitian ini, sebagai berikut:

\section{1) Triangulasi Teknik}

Triangulasi teknik digunakan untuk menguji kredibilitas data yang dilakukan dengan cara mengecek data kepada sumber yang sama dengan cara yang berbeda, misalnya peneliti sudah melakukan wawancara, data yang didapatkan melalui wawancara lalu dicek lagi dengan observasi secara langsung, kemudian melakukan dokumentasi (Sugiyono, 2018).

2) Meningkatkan Ketekunan

Meningkatkan ketekunan berarti melakukan pengamatan secara lebih cermat dan berkesinambungan, dengan cara tersebut maka kepastian data yang sudah didapatkan oleh peneliti dan urutan peristiwa akan direkam secara pasti dan sistematis (Sugiyono, 2018).

3) Menggunakan Bahan Referensi Bahan referensi disini adalah dengan adanya bukti pendukung untuk memperkuat dan membuktikan data yang sudah ditemukan di lapangan penelitian (Moleong, 2017) .

\section{HASIL DAN PEMBAHASAN}

Dari hasil penelitian didapatkan tiga temuan utama yang dapat dideskripsikan dalam penelitian ini berdasarkan hasil wawancara, observasi dan dokumentasi serta diperkuat dengan kajian teori dari berbagai referensi. Tiga kategori utama tersebut yaitu pertama karakteristik anak kesulitan belajar berkaitan dengan kemampuan membaca, kedua kondisi temuan di lapangan khususnya di SDN Inklusif Sukasari 01 Pandeglang, ketiga solusi atau penanganan yang dapat dilakukan oleh guru dan orang tua.

\section{Karakteristik Anak Kesulitan Belajar \\ Berkaitan dengan Kemampuan Membaca}

Kesulitan belajar atau learning disability merupakan suatu kelainan yang membuat individu bersangkutan sulit melakukan kegiatan belajar secara efektif. (Kirk et al., 2009) berpendapat 
bahwa anak-anak dengan kesulitan belajar bagi sebagian orang nampak membingungkan dan paradoks. Terlepas dari kecerdasan yang hampir rata-rata atau lebih tinggi dari rata-rata, siswa dengan kesulitan belajar sering kali membuat sekolah menjadi sangat sulit. Sama seperti istilah ketidakmampuan belajar, anak-anak ini berjuang untuk belajar dan sering membutuhkan dukungan tambahan untuk membantu mereka berhasil di sekolah.

Anak-anak penyandang kesulitan belajar tidak melakukannya dengan baik di sekolah telah menarik perhatian dan membingungkan para peneliti dan praktisi di bidang membaca, kognisi, pidato dan pendengaran, neurologi, belajar, visi, audisi, dan pendidikan. Tidak semua anak penyandang kesulitan belajar memiliki serangkaian tantangan yang sama. Sebagian besar mengalami kesulitan belajar membaca, mengeja, dan menulis. Anak lain mungkin juga memiliki masalah dengan matematika atau dengan menerima informasi dan tugas. Beberapa mengalami kesulitan dengan semua bidang akademik.

Departemen Pendidikan AS (2004) memberi definisi berikut:

1. Secara umum Istilah "specific learning disability" atau kesulitan belajar secara spesifik berarti gangguan dalam 1 atau lebih dari proses psikologis dasar yang terlibat dalam pemahaman atau dalam menggunakan bahasa, diucapkan atau ditulis, gangguan yang dapat memanifestasikan dirinya dalam kemampuan yang tidak sempurna untuk mendengarkan, berpikir, berbicara, menulis, mengeja, atau melakukan perhitungan matematika.

2. Gangguan yang termasuk istilah tersebut mencakup kondisi seperti salah persepsi, cedera otak, disfungsi otak minimal, disleksia, dan perkembangan afasia.

Disleksia dianggap sebagai gangguan dalam populasi kesulitan belajar, dan didefinisikan oleh Asosiasi Disleksia Internasional sebagai Salah satu dari beberapa kesulitan belajar yang berbeda, yaitu gangguan konstitusional berbahasa tertentu yang ditandai dengan kesulitan dalam decoding kata tunggal, biasanya mencerminkan pemrosesan fonologis yang tidak cukup. Kesulitan dalam decoding kata tunggal sering tak terduga dalam kaitannya dengan usia dan kemampuan kognitif dan akademik lainnya; mereka tidak termasuk dalam gangguan perkembangan umum atau gangguan sensorik. Disleksia dimanifestasikan dalam kesulitan variabel dengan berbagai bentuk bahasa, selain masalah dengan membaca, masalah mencolok dalam memperoleh kecakapan dalam menulis dan ejaan (Orton Dyslexia Research Committee, 1994).

Kesimpulan utama adalah bahwa anak-anak dengan disleksia memiliki otak yang beroperasi secara berbeda dari otak anak-anak tanpa disleksia (Miller et al, 2003 Rourke, 1991; Willingham, 2008; Willis, 2008). Meskipun orang dengan disleksia memiliki kesulitan dalam pemerolehan bahasa (membaca, ejaan, menulis, dan kesadaran fonologis), banyak yang memiliki kemampuan yang berkembang dengan baik dalam pemecahan masalah visual, spasial, motorik, dan nonverbal 
(Dickman, 1996).

Proses pembelajaran anak dengan kesulitan belajar membutuhkan beberapa strategi yang disesuaikan pada kondisi anak. Kesulitan membaca merupakan bagian dari kesulitan belajar pada kelompok masalah prestasi akademik. Guru dapat menganalisis dari karakteristik anak berdasarkan masalah yang dihadapi oleh anak, agar guru dapat memberikan solusi yang tepat bagi anak.

\section{Temuan di SDN Inklusif Sukasari 01}

\section{Pandeglang}

Berdasarkan hasil wawancara terhadap guru, pengamatan peneliti dan dokumentasi di lapangan didapatkan hasil temuan yang terjadi pada faris siswa kelas tiga SDN Inklusif Sukasari 01 Pandeglang. Perkembangan belajar faris bisa disebut disleksia karena kesulitan belajar pada bidang bahasa khususnya membaca. Penting untuk diingat bahwa tidak semua anak dengan kesulitan belajar memiliki disleksia dan bahwa disleksia sering dianggap sebagai istilah medis, sedangkan kesulitan belajar tertentu digunakan dalam aturan pendidikan. Faris memiliki kesulitan belajar di sekolah, dan pikirannya sering tidak fokus, yang menyebabkan kesulitan baginya di sekolah dan merupakan sumber frustasi bagi gurunya. Kesulitan faris cukup ekstrim sehingga gurunya merasa dia mungkin juga memiliki gangguan tidak dapat konsentrasi.

Faris memiliki kecerdasan rata-rata tetapi menghadapi masalah dengan membaca. Dia mengalami kesulitan mengatur ide-idenya dan sering terganggu. Masalah membacanya begitu parah sehingga ia hampir tidak dapat membaca. Karena hasil akademiknya yang buruk, temanteman kelasnya berpendapat dia "bodoh." Terlepas dari masalah akademik ini, faris unggul dalam satu bidang yang lain yaitu bidang seni. Faris cukup kreatif dan menyukai kegiatan praktik atau demonstrasi langsung. Gurunya berpendapat bahwa faris membutuhkan banyak dukungan untuk belajar. Faris perlu guru khusus untuk mendampinginya dalam belajar membaca. Guru khusus tersebut meluangkan waktu dan mendampingi siswa-siswa yang mempunyai masalah sama seperti Faris. Bersama-sama dengan guru kelasnya serta melibatkan komunikasi dan kerjasama dengan orang tua, mencari cara untuk menggunakan kekuatannya dalam seni untuk meningkatkan harga dirinya dan membangun lebih banyak dukungan sosial baginya dengan temantemannya.

\section{Solusi yang dapat dilakukan Guru dan Orang} Tua

Salah satu bentuk layanan belajar bagi anak berkebutuhan khusus adalah pemberian treatment agar kesulitan dan hambatan belajar yang dialami siswa berkebutuhan khusus dapat diatasi. Harapannya adalah melalui layanan belajar yang tepat siswa yang berkebutuhan khusus dapat mengembangkan secara optimal potensi yang ada pada dirinya. Terdapat berbagai macam treatment yang dapat dilakukan untuk mengatasi kesulitan belajar pada anak disleksia, salah satunya adalah dengan penggunaan media sebagai alat bantu belajar. Peranan media sangat penting dalam pembelajaran mengingat media dapat bermanfaat 
untuk membantu menyampaikan informasi dari pembelajar kepada subjek ajar secara efektif. Terlebih lagi dengan diterapkannya kurikulum 2013 pembelajaran lebih ditekankan pada metode dan media. Pembelajaran konvensional yang identik dengan metode ceramah mulai ditinggalkan. Hal ini sesuai dengan pernyataan yang menyatakan bahwa di era globalisasi dan informasi penggunaan media pembelajaran tidak hanya sekedar tuntutan tetapi juga merupakan sebuah kebutuhan pembelajaran di era ini hendaknya mengedepankan metode pembelajaran yang mengarah pada keterampilan abad 21.

Berdasarkan adanya kesulitan belajar pada umumnya berkaitan dengan masalah kemampuan belajar atau masalah akademik; maka ada dua klasifikasi untuk penanganannya yaitu berasal dari persepsi medis dan persepsi psikoedukasional. Dua pendekatan tersebut mengemukakan hal-hal sebagai berikut:

1. Ahli medis beranggapan bahwa kesulitan belajar khusus disebabkan oleh kerusakan, menitikberatkan penanganan atau perawatan melalui obat untuk mengurangi tingkat kesulitan belajar dan gangguan yang diakibatkannya.

2. Psikolog dan ahli-ahli pendidikan beranggapan bahwa penyebab kesulitan belajar adalah karena adanya gangguan dalam keterampilan perseptual motorik.

Setelah menentukan diagnosa gangguan atau kesulitan pada seorang anak, maka bentuk penanggulangan /bantuan/ intervensi yang dapat diberikan sebagai berikut:
1. Remedial merupakan usaha perbaikan yang dilakukan pada fungsi belajar yang terhambat.

2. Tutoring merupakan bantuan yang diberikan langsung pada bidang studi yang terhambat dari siswa yang sudah duduk dibangku sekolah.

3. Kompensasi diberikan bila hambatan yang dimiliki anak berdampak negatif dalam proses pembentukan konsep dirinya.

Untuk penggunaan media dalam pembelajaran disesuaikan dengan situasi dan kondisi masing-masing lingkungan belajar. Aspek yang tidak kalah penting sebagai bahan pertimbangan pemilihan media pembelajaran adalah usia subjek belajar, dalam hal ini adalah siswa. Media pembelajaran yang sesuai dengan karakteristik anak sekolah dasar adalah media gambar. Hal ini harus disesuaikan dengan kondisi psikologis siswa Sekolah Dasar yang pada umumnya menyukai dengan hal-hal yang konkrit (Widodo, 2020).

Penggunaan media berbasis digital atau penerapan teknologi juga dapat menjadi pertimbangan untuk membantu memberikan kemudahan pada anak dengan kesulitan belajar. Seperti penelitian yang dilakukan (Pirani et al., 2013). Dalam penelitian tersebut dilakukan pengembangan dan rancangan software untuk memberikan solusi dalam membantu dan mendidik siswa dengan kesulitan belajar.

Berkaitan dengan penerapan teknologi juga digagas oleh peneliti (Al-Dababneh \& Al-Zboon, 2020). Hal yang menarik dari hasil penelitian ini adalah penggunaan alat bantu teknologi untuk 
anak-anak spesifik learning disability yang belajar di sekolah inklusif sangat menjanjikan. Penelitian menunjukkan bahwa peningkatan dalam kesulitan membaca, menulis, mengeja, dan matematika dimungkinkan bila ada penerapan yang tepat dari perangkat ini, dan guru yang memiliki keyakinan positif dan pelatihan yang memadai terkait alat bantu teknologi dipekerjakan. Penelitian ini menyimpulkan bahwa anak spesifik learning disability yang belajar di sekolah inklusif percaya akan pentingnya penggunaan dan integrasi alat bantu teknologi dalam proses pengajaran. Namun juga terungkap bahwa peserta menggunakan alat bantu teknologi yang sederhana, sehingga dapat disimpulkan bahwa peningkatan pelatihan dan ketersediaan sumber daya akan mendorong penerapan alat bantu teknologi lebih lanjut. Penelitian juga menunjukkan bahwa para guru mengungkapkan optimisme bahwa lebih banyak guru yang berpendidikan akhir-akhir ini akan lebih siap untuk menerapkan alat bantu teknologi.

\section{SIMPULAN}

Kesulitan belajar merupakan suatu kondisi dimana anak mengalami kesulitan untuk memahami atau menerima pembelajaran yang disebabkan oleh gangguan saraf pusat (otak). Sehingga anak mengalami gangguan yang mempengaruhi kemampuan untuk melakukan interpretasi apa yang dilihat dan didengar atau mendapat informasi dari bagian otak yang berbeda. Beberapa gangguan dapat mempengaruhi kegiatan belajar di sekolah salah satunya berupa gangguan belajar dalam membaca.
Banyak langkah diagnostik yang dapat ditempuh guru, untuk mengambil alternatif mengatasi kesulitan belajar terlebih dahulu melakukan beberapa langkah penting meliputi: menganalisis hasil diagnosis, menentukan strategi dan bidang kecakapan tertentu yang memerlukan perbaikan dan menyusun program perbaikan. Setelah langkah-langkah tersebut selesai, barulah pendidik melaksanakan langkah selanjutnya, yakni melaksanakan program perbaikan.

Salah satu bentuk layanan belajar bagi anak berkebutuhan khusus adalah pemberian treatment agar kesulitan dan hambatan belajar yang dialami siswa berkebutuhan khusus dapat diatasi. Harapannya adalah melalui layanan belajar yang tepat siswa yang berkebutuhan khusus dapat mengembangkan secara optimal potensi yang ada pada dirinya. Terdapat berbagai macam treatment yang dapat dilakukan untuk mengatasi kesulitan belajar pada anak disleksia, salah satunya adalah dengan penggunaan media sebagai alat bantu belajar. Peranan media sangat penting dalam pembelajaran mengingat media dapat bermanfaat untuk membantu menyampaikan informasi dari pembelajar kepada subjek ajar secara efektif. Media berbasis digital atau pemanfaatan teknologi pun dapat menjadi solusi dalam pembelajaran.

\section{DAFTAR PUSTAKA}

Al-Dababneh, K. A., \& Al-Zboon, E. K. (2020). Using assistive technologies in the curriculum of children with specific learning disabilities served in inclusion settings: teachers' beliefs and professionalism. Disability and Rehabilitation: Assistive Technology, $\quad 0(0), \quad 1-11$. https://doi.org/10.1080/17483107.2020.1752 824 
Anggito, A., \& Setiawan, J. (2018). Metodologi penelitian kualitatif. Sukabumi: CV Jejak (Jejak Publisher).

Kirk, S., Gallagher, J. J., Coleman, M. R., \& Anastasiow, N. (2009). Children Who Are Deaf or Hard of Hearing. In Educating Exceptional Children.

Milles, \& Huberman. (2013). Qualitative Data Analysis: A Methods Sourcebook. Los Angeles: SAGE Publications.

Moleong, L. (2017). Metodologi Penelitian Kualitatif. Bandung: PT Remaja Rosdakarya. Dipetik Desember 5, 2019

Nasional, P. K. B. P. dan P. D. P. (2007). Model Kurikulum Bagi Peserta Didik Yang Mengalami Kesulitan Belajar.

Ontario Rusmono, D. (2019). PENANGANAN BAGI SISWA DENGAN LEARNING DISABILITY YANG DAPAT DILAKUKAN OLEH ORANG TUA DAN GURU: LITERATURE REVIEW Danny Ontario Rusmono. JKKP: Jurnal Kesejahteraan Keluarga dan Pendidikan, 6(02), 133-140. https://doi.org/doi.org/10.21009/JKKP.062.0 8

Pirani, Z., Molvizadah, V., Abbas Sayyed, M., \& M., S. (2013). E-Learning Framework for Learning Disabled Children. International Journal of Computer Applications, 63(19), 38-42. https://doi.org/10.5120/10577-5703

Sugiyono. (2018). Metode Penelitian : Kuantitatif, Kualitatif, dan $R \& D$. Bandung: Alfabeta. Dipetik Desember 5, 2019

Suryandari, S. (2020). Jurnal inovasi pendidikan dasar. Jurnal Inovasi Pendidikan Dasar, $4(1), 23-29$.

Widodo, A. (2020). Analisis Penggunaan Media Gambar Berseri Untuk Meningkatkan Kemampuan Membaca Siswa Disleksia Di Sekolah Dasar. MAGISTRA: Media Pengembangan Ilmu Pendidikan Dasar Dan Keislaman, 11(1),. SELL Journal, 5(1), 55. https://doi.org/10.31942/mgs.v11i1.3457 